\title{
Preparation and Quality Evaluation of Flour and Biscuit from Sweet Potato
}

\author{
Sneha Srivastava, T.R.Genitha* and Vrijesh Yadav
}

Assistant Professor, Department of Food Process Engineering, Sam Higginbottom Institute of Agriculture Technology and Sciences, Allahabad-211007, India

\begin{abstract}
Experiments were conducted at Regional Food Research Analysis Centre Lucknow to utilize the Sweet potato flour for preparation of biscuits. The sweet potato tubers were brought from local market at Lucknow. The tubers were thoroughly sorted, washed, peeled, sliced, blanched, soaked, drained, dried and milled into flour. Sweet potato flour contains less amount of protein, although rich in dietary fiber content and carbohydrate, so a successful combination with wheat flour for biscuit production would be nutritionally advantageous. In this experiment Sweet potato flour was blended with wheat flour in ratio of $10 \%, 20 \%, 30 \%, 40 \%$ and $50 \%$. These samples were thereafter subjected to functional properties analysis. The proximate composition of the various flour blends used for the preparation of biscuits were determined using standard methods. The physico-chemical analysis \& sensory evaluation was done to know the acceptability of SPF biscuits. These were evaluated for sensory analysis that included color, flavor, taste, and overall acceptability. The SPF biscuits were analyzed for analytical and chemical analysis, which includes moisture content, fiber, fat and total ash. On the basis of nutritional value SPF biscuits containing $50 \%$ sweet potato flour is acceptable as it contains higher fiber content than other samples, at the same time on the basis of sensory evaluation SPF biscuit containing $50 \%$ sweet potato flour scored high score for over-all acceptability. The marketing costs for different treatments of SPF biscuits are around $32 \mathrm{Rs}$ per $\mathrm{kg}$ of final product, this is profitable in all aspects due to its nutritive value and it is economical.
\end{abstract}

Keywords: Sweet potato Flour; Sweet potato Biscuits; Physicochemical Analysis; Sensory Evaluation

\section{Introduction}

The sweet potato Ipomoea batatas (L.) belongs to the Convolvulaceae or morning glory family [1]. Sweet potato is among the world's most important and under-exploited crop. It is commonly referred to a subsistence, food security or famine relief crop, its uses have diversified considerably in the developing countries [2].

India has a long history of sweet potato cultivation. It is an important tuber crop grown in almost all parts of India. Sweet Potato is cultivated in about 0.14 million hectares. In India, the area covered under this crop in 2005 , was $100,000 \mathrm{Ha}$ and production was and has an annual production of 1.17 million tones. The major area under sweet potato in India is spread over four states: Orissa, Bihar, Uttar Pradesh and West Bengal. Sweet potato is used mostly as vegetable and snack food. Industrial utilization is very negligible causing negative growth in area and production. Vines are used as animal feed in some states like Uttar Pradesh, Bihar, Orissa and North Eastern Region [3]. About 22\% of sweet potato production of the country is done in Uttar Pradesh.

Sweet potatoes are good sources of vitamins $\mathrm{C}$ and $\mathrm{E}$ as well as dietary fiber, potassium, and iron, and they are low in fat and cholesterol. It serves as an important protein source for many world populations and is an important source of starch and other carbohydrates the human body needs [4]. The carbohydrate content of the storage roots varies from $25 \%$ to $30 \%$, while the rest is composed of water (58\%-72\%). Sweet potato contains various micro-nutrients. Substantial quantities of vitamin $\mathrm{C}$, moderate quantities of thiamin (vitamin B1), riboflavin (vitamin B2) and niacin, some quantities of panthothenic acid (vitamin B5), pyridoxine (vitamin B6), folic acid and satisfactory quantities of vitamin E are present. Sweet potato also contains some essential minerals and trace elements having especially high quantities of iron. Two other important minerals present are potassium and calcium [5]. Moderate quantities of zinc, sodium, magnesium and manganese are also present [6].
Fresh sweet potato roots are bulky and highly perishable therefore sweet potato roots can be sliced, dried, and ground in order to produce flour that remains in good condition for a long time. Sweet potato, either fresh, grated, cooked and mashed, or made into flour, could with high potential for success, replace the expensive wheat flour in making buns, chapatis (flat unleavened bread) and mandazis (doughnuts) [7]. The flour is used as a dough conditioner for bread, biscuit, and cake processing (it may substitute for up to $20 \%$ of wheat flour), as well as in gluten-free pancake preparation [8]. Sweet potato flour can add natural sweetness, color, and flavor to processed food products. It can also serve as a source of energy and nutrients and minerals and contributes to the daily nutrient needs for $\beta$-carotene, thiamin, iron, vitamin $C$, and protein. Sweet potato flour provides $14 \%-28 \%$ of the dietary reference intake (DRI) for magnesium and 20-39\% for potassium [9].

The flour can be stored for 6 months or more in sealed containers. It can be used as a substitute for wheat flour in the following amounts: $100 \%$ in white sauces, $25-50 \%$ in cookies, cakes and flat breads, and 15 $20 \%$ in breads. SP flour would be marketed as a low cost alternative for imported wheat flour, especially for snack food and noodle producers. Small flour production and use trials were made using local varieties [10]. Much technical research on SP flour carried out in developing country institutions has focused on product formulation using SP flour rather than on efficient, low-cost, small scale processes to produce the

${ }^{*}$ Corresponding author: T.R.Genitha, Assistant Professor, Department of Food Process Engineering, Sam Higginbottom Institute of Agriculture Technology and Sciences, Allahabad-211007, India, E-mail: genithaimmanuel@yahoo.co.in

Received August 13, 2012; Accepted October 06, 2012; Published October 13 2012

Citation: Srivastava S, Genitha TR, Yadav V (2012) Preparation and Quality Evaluation of Flour and Biscuit from Sweet Potato. J Food Process Technol 3:192. doi:10.4172/2157-7110.1000192

Copyright: (c) 2012 Srivastava S, et al. This is an open-access article distributed under the terms of the Creative Commons Attribution License, which permits unrestricted use, distribution, and reproduction in any medium, provided the original author and source are credited. 
Citation: Srivastava S, Genitha TR, Yadav V (2012) Preparation and Quality Evaluation of Flour and Biscuit from Sweet Potato. J Food Process

flour [11]. Sweet potato based products are of high quality and could compete with existing products in the market [12].

An approach in the present study was to replace the wheat flour in cookies by sweet potato flour (gluten free flours) in order to increase the fibre and other nutrients. The objective was to develop cookies with good taste texture and appearance, which resembles as closely as possible to the wheat flour based product. The textural property and sensory quality of cookies are taken into consideration to improve the quality of cookies.

\section{Materials and Methods}

The experimental studies were carried out in laboratories of Regional Food Research and Analysis Centre, Lucknow. The methodology adopted has been described under the below.

\section{Procurement of raw material}

Good quality of sweet potatoes without any bruises and other major ingredients that is wheat flour, sugar, baking powder, milk and emulsifier were purchased from local market of Lucknow.

\section{Experimental plan}

The experimental plan used for the present research is given in table 1-3. Figure 1 shows the flow chart for the preparation of sweet potato flour and figure 2 shows the flow chart for the preparation of biscuits. Table 2 shows the different combination of sweet potato flour and wheat flour for biscuit preparation and the ingredients used in the preparation of Biscuits (in $\mathrm{g}$ ) are tabulated in table 3.

\begin{tabular}{|l|l|l|l|}
\hline S.No & Parameter & Level & Description \\
\hline 1. & Product & 1 & Biscuit \\
\hline 2. & Ingredients & 4 & $\begin{array}{l}\text { Baking powder, oil } \\
\text { Wheat flour, sugar, }\end{array}$ \\
\hline 3. & Samples & 6 & T-0, T-1, T-2, T-3, T-4, T-5 \\
\hline 4. & Analysis & 3 & $\begin{array}{l}\text { Physio chemical Analysis (8), sensory- } \\
\text { analysis(6), physical analysis(5) }\end{array}$ \\
\hline 5. & Packaging material & 1 & HDPE \\
\hline 6. & Storage condition & 1 & Ambient temp \\
\hline & & & \\
\hline
\end{tabular}

Treatment Combination

Table 1: Experimental Plan.

\begin{tabular}{|l|l|l|}
\hline Treatment & Sweet potato flour(\% & Wheat flour $(\%$ \\
\hline$T_{0}$ (control) & 00 & 100 \\
\hline$T_{1}$ & 20 & 80 \\
\hline$T_{2}$ & 40 & 60 \\
\hline$T_{3}$ & 60 & 40 \\
\hline$T_{4}$ & 80 & 20 \\
\hline$T_{5}$ & 100 & 00 \\
\hline
\end{tabular}

Table 2: Different combination of sweet potato flour and wheat flour for biscuit.

\begin{tabular}{|l|l|l|l|l|l|l|l|}
\hline S.No. & Ingredients & T-0 & T-1 & T-2 & T-3 & T-4 & T-5 \\
\hline 1. & SPF & 00 & 20 & 40 & 60 & 80 & 100 \\
\hline 2. & WWF & 100 & 80 & 60 & 40 & 20 & 00 \\
\hline 3. & Salt & 0.5 & 0.5 & 0.5 & 0.5 & 0.5 & 0.5 \\
\hline 4. & Sugar & 50 & 50 & 50 & 50 & 50 & 50 \\
\hline 5. & Baking powder & 2 & 2 & 2 & 2 & 2 & 2 \\
\hline 6. & Ghee & 20 & 20 & 20 & 20 & 20 & 20 \\
\hline
\end{tabular}

Table 3: Ingredients used in the preparation of Biscuits (in g).

\section{Preparation of sweet potato flour}

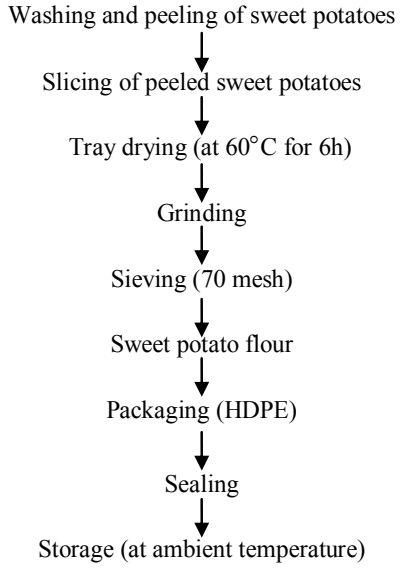

Figure 1: Flow chart for the preparation of sweet potato flour Preparation of Biscuits.

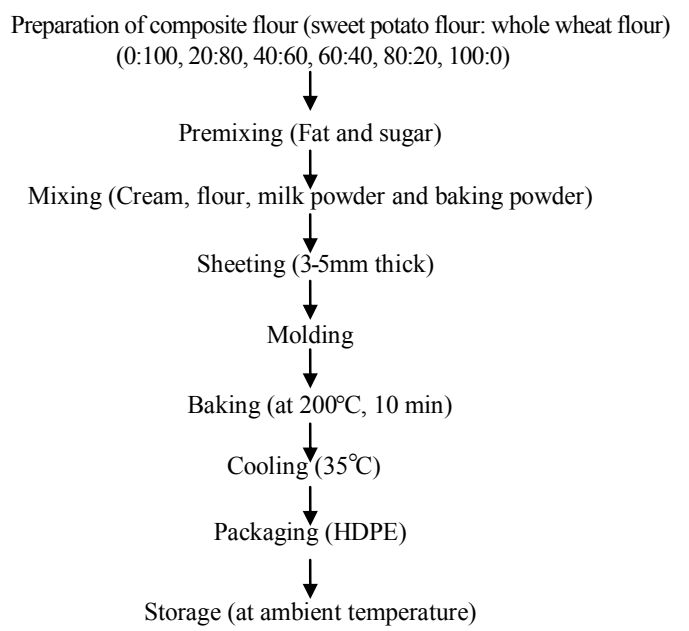

Figure 2: Flow chart for the Preparation of Biscuits.

Physico-chemical analysis for sweet potato flour and the developed biscuits

Moisture content: The moisture content of the developed biscuit was determined by the method described in AACC (2000).

$$
\text { moisture }(\%)(w . b .)=\frac{(w 1-w 2)}{w 1-w} \times 100
$$

Where,

$\mathrm{W}=$ weight in gram of the empty moisture dish.

$\mathrm{W} 1=$ weight in gram of the moisture dish with the material before drying.

W2=weight in gram of the moisture dish with the material after drying.

Ash content: The ash content was determined by the method described in AACC (2000), Method no. 08-01.

total ash $\%=\frac{(w 2-w 1)}{w 1-w} \times 100$ 
Citation: Srivastava S, Genitha TR, Yadav V (2012) Preparation and Quality Evaluation of Flour and Biscuit from Sweet Potato. J Food Process Technol 3:192. doi:10.4172/2157-7110.1000192

Page 3 of 5

Where,

$\mathrm{W}=$ weight in gram of the empty dish.

W1=weight in gram of the dish with dried material taken for test.

W2=weight in gram of the dish with the ash.

Fat content: The fat content was determined by the method described in AACC (2000), Method no. 30- 25.

$$
f a t \%=\frac{\text { weight of sample after drying }- \text { weight of empty cup }}{\text { weight of sampletaken }} \times 100
$$

Reducing, non-reducing and total sugar: Sugar was estimated as per methods described by Ians Eynons.

reducing sugar $=\frac{\text { dye factor } \times \text { volume makeup }}{\text { t.v.reading } \times \text { sample weight }} \times 100$

I.S.Sugar $=\frac{\text { dye factor } \times \text { volume makeup }}{\text { t.v.reading } \times \text { sample weight }} \times 100$

sucrose $=($ I.S.Sugar - R.D.Sugar $) 0.95 \%$

Totalsugar $=$ R.D.Sugar + sucrose $\%$

Where,

I.S.=Invert sugar

R.D.=Reducing sugar

\section{Physical parameters}

Spread ratio: The spread ratio was determined by using this formula.

$$
\text { spread ratio }=\frac{\text { diameter }(\mathrm{mm})}{\text { thickness }(\mathrm{mm})}
$$

Thickness: The thickness was measured in $\mathrm{mm}$ by screw gauge.

Volume: Volume of biscuit is defined as the area of the biscuit multiplied by thickness.

$$
\text { volume }\left(\mathrm{cm}^{3}\right)=\frac{d^{2} \pi T}{4}
$$

$\mathrm{t}=$ Average thickness of biscuit $(\mathrm{mm})$

$\mathrm{d}=$ Diameter of biscuit $(\mathrm{mm})$

Diameter: The diameter was measured in $\mathrm{mm}$ by Vernier caliper.

Density: After calculating volume, density was obtained by ratio of weight of volume (AACC 1983).

$$
\text { density }\left(\frac{\mathrm{g}}{\mathrm{cm}^{3}}\right)=\frac{\text { mass of sample }(\mathrm{g})}{\text { volume of sample }\left(\mathrm{cm}^{3}\right)}
$$

Sensory analysis of developed biscuits: The samples were evaluated on the basis of color, taste, flavor, texture and overall acceptability by a panel of judges using 9-point hedonic scale.

\section{Results and Discussion}

\section{Physico-chemical analysis of developed sweet potato flour}

Proximate analysis of sweet potato flour is presented in table 4 . The

\begin{tabular}{|l|l|l|}
\hline S.No. & Constituents & Percentage (\%) \\
\hline 1. & Moisture (d.b.) & $7.9 \pm 0.2$ \\
\hline 2. & Starch & $76.2 \pm 0.65$ \\
\hline 3. & Reducing sugar & $5.7 \pm 0.1$ \\
\hline 4. & Total sugar & $10.6 \pm 0.26$ \\
\hline 5. & Ash & $2.54 \pm 0.6$ \\
\hline 6. & Water absorption & $5.52 \pm 0.0$ \\
\hline 7. & Fiber & $1.038 \pm 0.3$ \\
\hline 8. & Fat & $0.52 \pm 0.01$ \\
\hline
\end{tabular}

Table 4: Physico-chemical analysis of Sweet Potato Flour.

\begin{tabular}{|l|l|l|l|l|}
\hline $\begin{array}{l}\text { No. of } \\
\text { Treatment }\end{array}$ & Diameter $\mathbf{( c m )}$ & Thickness $\mathbf{( c m )}$ & Volume $\left.\mathbf{( c m}^{3}\right)$ & Density $\mathbf{( g / \mathbf { c m } ^ { 3 } )}$ \\
\hline $\mathrm{T}_{0}$ & 4.50 & 0.86 & 13.6 & 0.86 \\
\hline $\mathrm{T}_{1}$ & 4.48 & 0.84 & 13.2 & 0.89 \\
\hline $\mathrm{T}_{2}$ & 4.46 & 0.84 & 13.1 & 0.89 \\
\hline $\mathrm{T}_{3}$ & 4.42 & 0.83 & 12.7 & 0.92 \\
\hline $\mathrm{T}_{4}$ & 4.41 & 0.83 & 12.6 & 0.93 \\
\hline $\mathrm{T}_{5}$ & 4.40 & 0.82 & 12.4 & 0.94 \\
\hline
\end{tabular}

Table 5: Physical parameters of developed biscuits.

\begin{tabular}{|l|l|l|l|l|}
\hline Treatments & $\begin{array}{c}\text { Moisture content (\%) } \\
\text { (d.b.) }\end{array}$ & Ash (\%) & Fiber (\%) & Fat (\%) \\
\hline $\mathrm{T}_{0}$ & 1.329 & 2.82 & 1.94 & 8.50 \\
\hline $\mathrm{T}_{1}$ & 1.343 & 2.83 & 2.71 & 6.06 \\
\hline $\mathrm{T}_{2}$ & 1.352 & 2.92 & 4.04 & 5.53 \\
\hline $\mathrm{T}_{3}$ & 1.355 & 3.05 & 6.05 & 5.10 \\
\hline $\mathrm{T}_{4}$ & 1.362 & 3.12 & 8.04 & 4.04 \\
\hline $\mathrm{T}_{5}$ & 1.369 & 3.15 & 8.50 & 4.02 \\
\hline
\end{tabular}

Table 6: Quality Analysis of Standardized biscuits after Baking.

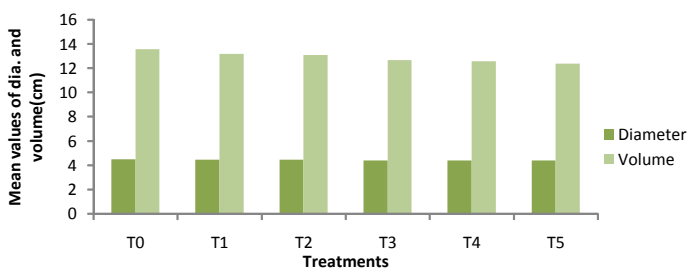

Figure 3: Effect of treatments on volume and diameter of sweet potato biscuit.

ash content of sweet potato flour was $2.54 \%$ and the moisture content was $7.9 \%$. The starch content in sweet potatoes was $76.2 \%$ where as total sugar was found to be $10.6 \%$. The reducing sugar was calculated to be $5.7 \%$ whereas fat was found to be $0.52 \%$. So, it can be analyzed that sweet potato has good nutritional quality.

\section{Physical parameters of developed biscuits}

Table 5, 6 shows that there was a significant decrease in the diameter of control (T0) and different treatments (T1, T2, T3, T4, T5) after incorporating biscuits with Sweet potato flour. There was a slight decrease in the thickness, spread ratio, volume and density of control (T0) and different treatments (T1, T2, T3, T4, T5) after incorporating biscuits with Sweet potato flour. The results were in conformity with [13]. Figure 3 shows the effect of treatments on volume and diameter while figure 4 shows the thickness and Density of sweet potato incorporated biscuit.

The result showed that increase in level of sweet potato flour resulted in linear decrease of thickness and diameter of biscuit. This 


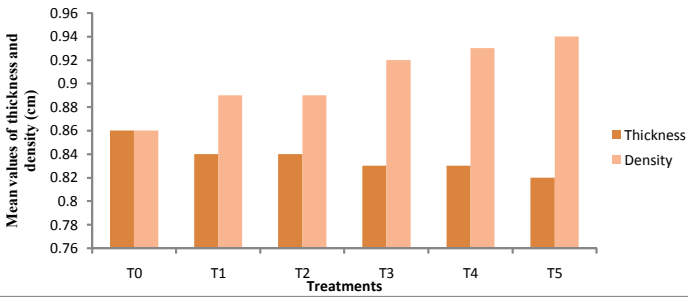

Figure 4: Effect of treatments on thickness and density of sweet potato biscuit.

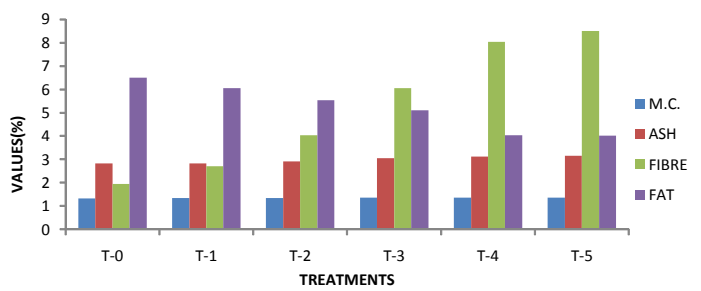

Figure 5: Physico-chemical quality of sweet potato biscuit for various treatments.

\begin{tabular}{|l|l|l|l|l|l|}
\hline Treatments & Colour & Taste & Flavor & Texture & OAA \\
\hline $\mathrm{T}_{0}$ & 8.66 & 8.66 & 8.00 & 8.66 & 9.00 \\
\hline $\mathrm{T}_{1}$ & 8.00 & 8.00 & 7.33 & 8.33 & 8.00 \\
\hline $\mathrm{T}_{2}$ & 8.33 & 8.66 & 8.33 & 8.66 & 8.66 \\
\hline $\mathrm{T}_{3}$ & 7.66 & 7.33 & 7.66 & 7.33 & 7.33 \\
\hline $\mathrm{T}_{4}$ & 7.52 & 7.22 & 7.23 & 7.20 & 7.25 \\
\hline $\mathrm{T}_{5}$ & 7.01 & 6.01 & 6.66 & 6.01 & 7.00 \\
\hline
\end{tabular}

Table 7: Sensory Evaluation of developed biscuits.

is due to the higher water holding capacity of sweet potato flour. The volume of sweet potato biscuit decreased linearly whereas, density increased in the similar manner. This may be due to higher fiber content in the flour.

\section{Physico-chemical analysis of sweet potato biscuit}

During the present investigation no significant difference was found in the percent moisture content, and ash content was observed on increasing the incorporation of SPF in the treatments (i.e. T0, T1, T2, T3, T4 and T5). Whereas, there was a significant change in the values of fiber and fat content. This was because in the present study the formulation was based on 00:100\%, 20:80\%, 40:60\%, 60:40\%, 80:20\%, 100:00\% of sweet potato flour and whole wheat flour blend. Sweet potato flour has a lower moisture content but high starch and fiber content whereas, whole wheat flour is rich in moisture, protein and carbohydrate content. Therefore, a significant difference was observed between the samples. The moisture content of control and the sample biscuits was between the range of $1.329 \%$ to $1.369 \%$. But the ash content of control and the sample biscuits was between the range of $2.82 \%$ to $3.15 \%$. The fiber content was between the range of $1.94 \%$ to $8.50 \%$. Fat content varied from $6.50 \%$ to $4.0 \%$ which was within the acceptable limits for biscuits. Figure 5 shows the physico-chemical quality of sweet potato biscuit for various treatments (Table 6).

The moisture content of biscuits increased linearly with increase in concentration of sweet potato, this is attributed to high water binding capacity of sweet potato which retained higher moisture content in ultimate products. The results for moisture content of the biscuit were similar with the results obtained by [14], who incorporated green gram flour in preparation of the biscuits.
The ash content of biscuits increased significantly due to higher ash content of sweet potato and due to externally added fat during biscuits preparation. Both refined wheat flour and sweet potato flour were having lower fat content and hence the total fat content in samples were similar where as there was slight reduction in fat content with increase in sweet potato flour incorporation. The results of proximate composition of sweet potato based biscuits are similar with the results obtained by [15].

The fiber content of biscuit increased significantly, due to higher fiber content of sweet potato flour. As fiber absorbs large amount of water, it gives a sensation of fullness (having an appetite completely satisfied).

\section{Sensory evaluation for product standardization}

Biscuits supplemented by different levels of substitutions of sweet potato flour were sensory evaluated and compared with control biscuits $100 \%$ whole wheat flour.

Data indicated that the percent score of biscuits containing $40 \%$ sweet potato flour were found to be the most acceptable. At $40 \%$ level of incorporation, all the attributes scored highest level. The color scores of biscuits with $40 \%$ sweet potato flour reached maximum than to the rest of the proportions similar to the control sample. Thus, incorporation of sweet potato flour at $40 \%$ level improved the sensory attributes namely texture, flavor, color and over all acceptability [13]. The nutritional quality of the developed biscuits was enhanced due to the addition of Sweet potato flour. Thus, the sensory evaluation table 7 depicts that highest amount of sweet potato flour that can be incorporated to develop acceptable biscuit was $40 \%$, i.e. sample T2 was the best regarding all sensory attributes.

The score of colour reduced significantly to 7.01, this was due to increasing level of sweet potato flour which gave a dark brown color to biscuit which was not liked much by the panelist. Similarly, the score of taste, flavor and texture also reduced significantly. This was because of typical flavor component and caramelization of free sugar in sweet potato flour during baking [13].

\section{Conclusion}

It was found that Sweet potato contains a limited amount of protein, although rich in dietary fiber content and carbohydrate, so a successful combination with wheat flour for biscuit production would be nutritionally advantageous. Sweet potato flour with wheat flour had significant effect on the functional properties of the flour blends. Blending SPF with WF up to $20 \%$ level produced samples which can be used for production of bakery goods with improved functional properties. Incorporation of $40 \%$ sweet potato flour yielded approximately similar results compared with wheat flour cookies with improved nutritional value and texture. This work showed the peculiar characteristics (moisture, protein, ash, fiber and fat) of sweet potato flour. The results obtained could be very valuable in decision making for industries that want to take nutritional advantage of sweet potato flour as alternative or supplement to cereal flours. Sweet potato flour could be useful in the manufacture of highly nutritious cookies.

\section{References}

1. Jones (1965) Genetic variation in color of sweet potato flour related to its use in wheat-based composite flour products. Cereal Chemistry 74: 681-686.

2. Sathe SK, Salunkhe DK (1999) Functional properties of the great northern bean protein: emulsion, foaming, viscosity and gelation properties. J. Food Sci 46: 71-76. 
Citation: Srivastava S, Genitha TR, Yadav V (2012) Preparation and Quality Evaluation of Flour and Biscuit from Sweet Potato. J Food Process Technol 3:192. doi:10.4172/2157-7110.1000192

Page 5 of 5

3. FAO (1984) Approved methods of the Food and Agriculture organization 10th ed. Method 44-15A, 44-13, 08-01, 30-10 and 32-10.The Association: St. Paul, MN.

4. Benjamin (2007) Rheology and chemistry of dough. In: Pomeranz Y (ed) Wheat chemistry and Technology. (3rd edn), American Association of Cereal Chemists, Minnesota.

5. Woolfe JA (1992) Sweet potato: An untapped resource. Cambridge, UK: Cambridge University Press.

6. Antia (2006) Effect of texture modifiers on the physicochemical and sensory properties of dried fufu. Food Sci. Technol. Int 11: 373-382.

7. Hagenimana V, Carey EE, Gichuki ST, Oyunga MA, Imungi JK (1998) Carotenoid content after drying and processing sweetpotato products. Ecol Food Nutr 37: 450-473.

8. Shih LO, Adebowale AA, Tafa SO (2006) Proximate, Functional, Pasting and Sensory Qualities of Instant Yam Flour. A Paper Presented at the 14th ISTRC Symposium, Central Tuber Crops Research Institute, Trivandrum, Kerala State, India.
9. Van Hal M (2000) Quality of sweet potato flour during processing and storage. Food Rev Int 16: 1-37.

10. Peters D, Wheatley C (1997) Small scale agro-enterprises provide opportunities for income generation: Sweet potato flour in East Java, Indonesia. Quarterly Journal of International Agriculture.

11. Palomar L (1992) Formulation and evaluation of sweetpotato and cassava chiffon cake. In Product Development for Root and Tuber Crops, Vol. I-Asia eds Scott G, Wiersema S, \& Ferguson P. International Potato Center (CIP), Lima, Peru pp 41-50.

12. Hagenimana, Owori (1996) Breakfast cereal, kid-style. Food Product Design 119: $1-7$.

13. Singh (2008) Development of high protein biscuits from green gram flour manufactures. Applied Science Publisher Ltd., London, UK.

14. Kalpana M (2003) Use of wheat-sweet potato composite flours in yellowalkaline and white-salted noodles.

15. Chauhan and Bains (1985) Crude protein, minerals and total carotenoids in sweet potatoes. Journal of Food Science 50: 1768. 